\title{
Volatile compounds in Medlar fruit (Mespilus germanica L.) at two ripening stages
}

\author{
Milovan M. Veličković ${ }^{1}$, Dragan D. Radivojević ${ }^{1}$, Čedo Đ. Oparnica ${ }^{1}$, Ninoslav J. Nikićević ${ }^{1}$, Marijana B. \\ Živković ${ }^{2}$, Neda O. Đorđević ${ }^{2}$, Vlatka. E. Vajs ${ }^{2}$, Vele V. Tešević ${ }^{3}$ \\ ${ }^{1}$ University of Belgrade, Faculty of Agriculture, Belgrade, Serbia \\ ${ }^{2}$ University of Belgrade, Institute for Chemistry, Technology and Metallurgy, Belgrade, Serbia \\ ${ }^{3}$ University of Belgrade, Faculty of Chemistry, Belgrade, Serbia
}

\begin{abstract}
Medlar is the fruit of Mespilus germanica L. in the family of Rosaceae. The fruit can be eaten only if "bletted" (softened by frost or longer storage). The effect of the maturation stages on the volatile compounds of the medlar fruit was investigated during two different stages. Volatile flavour substances were isolated from the minced pulp of unripe and full ripe medlar fruits by simultaneous steam distillation extraction (SDE) with methylene chloride as the extracting solvent. The concentrate was analysed by GC-FID-MS. Hexanoic and hexadecanoic acids were the predominant acids, hexanal and (E)-2-hexenal were the predominant aldehydes, (Z)-3-hexenol and hexanol were the predominant alcohols, with $p$-cymene, terpinen-4-ol, and $\gamma$ terpinene (the terpenes responsible for the characteristic medlar flavour) being also present. The $\mathrm{C} 6$ aliphatic compounds, such as hexanal and (E)-2-hexenal, were observed as the major volatile constituents in the green stage. In contrast, hexanol and (Z)-3-hexenol were the main volatiles in ripe fruits.
\end{abstract}

Keywords: Medlar, flavor, ripening, GC/MS.

RESEARCH NOTE

UDC 634.15:547.9:631.547.66

Hem. Ind. 67 (3) 437-441 (2013)

doi: 10.2298/HEMIND120611085V

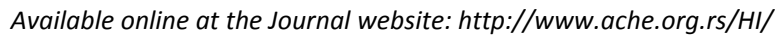

The medlar (Mespilus germanica L.) is a member of the Rosaceae family and is native to the eastern Mediterranean area. M. germanica was already being cultivated about three thousand years ago in the Caspian Sea region of northern Iran. Medlar is a climacteric fruit, and as such, important biochemical changes occur during the respiratory climacteric, just before the full maturation stage.

The fruits are hard to harvest, and they become brown, soft, sweet and edible after and during storage [1]. They can be kept in cold storage for several months. The flavor of medlar fruit is described as rich, cider and wine-like, and also resembles that of dried apples or quinces. The fruits contain sugar, organic acid, amino acids and tannins. Fructose, glucose and sucrose were identified as the principal sugars and their levels varied remarkably during development [2]. Fatty acids in med$\operatorname{lar}(M$. germanica) mesocarp at different stages of ripening were measured, and were found to be mainly palmitic acid, linoleic acid and $\alpha$-linolenic acid [3]. Medlar has rich nutritional properties, especially in the mineral content ( $\mathrm{Al}, \mathrm{Ba}, \mathrm{Ca}, \mathrm{Cu}, \mathrm{Co}, \mathrm{Fe}, \mathrm{K}, \mathrm{Li}, \mathrm{Mg}, \mathrm{Mn}$, $\mathrm{Na}, \mathrm{Ni}, \mathrm{P}, \mathrm{Sr}, \mathrm{Ti}$ and $\mathrm{Zn}$ ), with the highest accumulation of potassium [4]. Changes of nutritionally important chemical constituents (sugars, organic acids, and fatty

Correspondence: V.V. Tešević, University of Belgrade, Faculty of Chemistry, Studentski trg 12-16, 11000 Belgrade, Serbia.

E-mail: vtesevic@chem.bg.ac.rs

Paper received: 11 June, 2012

Paper accepted: 16 July, 2012 acids) of widely sold and consumed medlar during the post-harvest period were reported [5]. Medlar fruits can contain twenty different fatty acids, ten of which are saturated and ten unsaturated. The total fatty acid content of the fruit changed throughout development, reaching a maximum value of $6.121 \mu \mathrm{g} / \mathrm{g}$ dry wt. by mid-August and thereafter declining to a value of 2.583 $\mu \mathrm{g} / \mathrm{g}$ dry wt. in the fully ripe fruit (October) [6]. Linoleic acid (C18:2n-6) contributed most to the percent composition of the total fatty acids in the lipid extract at all stages of development. Eight phenolic acids (protocatechuic, 4-hydroxybenzoic, syringic, 3-hydroxybenzoic, caffeic, salicylic, 4-coumaric and sinapic) were determined by HPLC-MS during five stages of fruit maturity. The concentrations of phenolic acids mostly decreased as the fruit ripening progressed, except for insoluble ester-bound phenolics, which increased at the early stages of maturity and decreased only during the ripe to over-ripe stage of maturity [7].

Most of the volatile components of fruits are saturated and unsaturated aliphatic compounds with oxygenated functional groups such as ester, alcohol, acid, aldehyde, ketone or lactone. These substances originated during the ripening process through different metabolic paths. Thus, the fatty acid path produces esters and C6 compounds, via the lipoxygenase [8]. Through the isoprenoid pathway, the group of terpenes are biogenerated either via mevalonate or no-mevalonate. And finally, the shikimic acid path is involved in 
the biosynthesis of phenylpropanoids, which are the precursors of many aromatic compounds [9].

In a previous study, only three components in the volatile oil of medlar seeds were identified: benzaldehyde, pentadecane and tetradecane [10]. Plant physiologists and food analysts have become interested in the nature and chemical composition of medlar during maturation and ripening. Romero-Rodriguez et al. described some of the physical (weight, colour, firmness), physicochemical ( $\mathrm{pH}$, soluble solids) and chemical (moisture, soluble sugars, starch, etc.) changes that occur during maturation of Spanish medlars [11]. Rop et al. investigated ascorbic acid (AA) and total phenolic compound content with respect to the total antioxidant activity. In addition, selected micronutrients and macronutrients were monitored [12].

Many fruits produce in excess of 100 volatile aroma compounds, although generally a relatively small percentage of these are considered to be major contributors to the unique flavor of a particular fruit $[13,14]$. Lipid components in fruits are presumed to contribute to characteristic aroma and flavor during ripening. These are essentially considered as precursors for various odorous volatile compounds [15] and also contribute to nutritional value of fruit [16].

The aim of this research was to determine the changes in volatile composition of medlar fruits during their two ripening stages: unripe and fully ripe stage. To the best of our knowledge, no previous studies have been reported on the volatile composition of medlar fruits.

\section{MATERIAL AND METHODS}

\section{Material}

Five solitary trees of domestic variety of medlar (Mespilus germanica) in the Topola region, Central Serbia, were used as experimental material. All fruits from experimental trees were harvested at physiological stage of maturity. Twenty fruits per tree were randomly selected and divided into two samples. Fruits from the first sample were used to determine volatile compounds in their unripe stage. Fruits from the second sample were stored in cold storage until the fully ripe stage.

\section{Isolation of volatile compounds}

From both fresh fruits samples (50 g), crude essential oil was obtained by $2 \mathrm{~h}$ distillation-extraction in a Lickens-Nickerson apparatus. The volatiles were collected in $\mathrm{CH}_{2} \mathrm{Cl}_{2}$.

\section{Analysis of volatile compounds}

\section{Gas chromatography/mass spectrometry analysis}

The GC-MS analysis was performed using an Agilent 7890 gas chromatograph coupled to an Agilent 5975 C mass selective detector (MSD) in the positive ion electron impact (EI) mode. The separation was achieved using an HP-5MS fused silica capillary column, $30 \mathrm{~m} \times$ $0.25 \mathrm{~mm}$ i.d., $0.25 \mu \mathrm{m}$ film thickness. GC oven temperature was programmed from 60 to $285^{\circ} \mathrm{C}$ at a rate of $4.3^{\circ} \mathrm{C} / \mathrm{min}$. Helium was used as carrier gas; inlet pressure was $25 \mathrm{kPa}$; linear velocity: $1 \mathrm{~mL} / \mathrm{min}$ at $210{ }^{\circ} \mathrm{C}$. Injector temperature: $250{ }^{\circ} \mathrm{C}$. Injection mode: split 1:50. MS scan conditions: source temperature, $200^{\circ} \mathrm{C}$; interface temperature, $250{ }^{\circ} \mathrm{C}$; $\mathrm{E}$ energy, $70 \mathrm{eV}$; mass scan range, 40-350 amu.

\section{Compounds identification}

A library search and mass spectral deconvolution and extraction were performed using NIST AMDIS (Automated Mass Spectral Deconvolution and Identification System) software version 2.4, using retention index (RI) calibration data analysis parameters with "strong" level and 7\% penalty for compounds without an RI. The retention indices were experimentally determined using the standard method involving retention times of $n$-alkanes, injected after the essential oil under the same chromatographic conditions. The search was performed against our own library, containing 4951 spectra. The percentage (relative) of the identified compounds was computed from the GC peak area.

\section{RESULTS AND DISCUSSION}

The chemical compounds that were found in the fully ripe and unripe stages were aldehydes, alcohols, esters, acids and terpenes (Table 1). Among them, C-6 aldehydes and alcohols were quantitatively dominant.

Figure 1 shows the chromatogram of immature fruits. In this stage, the aldehyde compounds class is predominant. The major components are hexenal and (E)-2-hexenal, 32.81 and $43.47 \%$, respectively. The composition at this stage is typical of immature fruits or fruits that are in the physiologic maturity period.

Figure 2 shows the chromatogram of fruits in their maturity stage. Relative proportions of acids increased. Hexanol and (Z)-3-hexenol, were major C-6 constituents in ripe fruits with 42.57 and $9.47 \%$, respectively. Another important class of compounds were the hydrocarbon sesquiterpenes. Within this group terpinen-4-ol $(12.56 \%), p$-cymene $(2.86 \%)$ and $\gamma$ terpiene $(1.02 \%)$ are present. Terpinen-4-ol is the major sesquiterpene hidrocarbon in the volatile compounds of mature fruits (12.56\%). Terpinen-4-ol, a monoterpene component of the essential oils of several aromatic plants, has already been found to show antimicrobial [17], antitumor [18] and acaricide activity [19]. The broad effects of this molecule also include its potential role as an antihypertensive [20] and as an anti-ulcer agent by virtue of its capacity to inhibit gastric acid and pepsin output [21]. Terpinen-4-ol is widely distributed in plants that vary 
Table 1. Volatile profile composition of unripe and ripe medlar fruits

\begin{tabular}{|c|c|c|c|}
\hline Compound & RI & \% Unripe & $\%$ Ripe \\
\hline \multicolumn{4}{|c|}{ Aldehydes } \\
\hline Hexanal & 804 & 32.81 & 6.53 \\
\hline Furfural & 826 & 0.12 & 2.12 \\
\hline (E)-2-Hexenal & 844 & 43.47 & $\operatorname{tr}$ \\
\hline Benzaldehyde & 956 & tr. & 0.40 \\
\hline Benzene acetaldehyde & 1042 & tr. & 0.28 \\
\hline$n$-Nonanal & 1100 & tr. & 0.27 \\
\hline (Z)-2-Nonen-1-al & 1158 & tr. & 0.99 \\
\hline (E)-2-Decenal & 1263 & tr. & 0.20 \\
\hline$(E, Z)-2,4$-Decadienal & 1296 & $\operatorname{tr}$. & 0.10 \\
\hline$(E, E)-2,4$-Decadienal & 1319 & tr. & 0.63 \\
\hline \multicolumn{4}{|c|}{ Alcohols } \\
\hline (Z)-3-Hexenol & 842 & 2.27 & 9.47 \\
\hline Hexanol & 853 & 12.12 & 42.57 \\
\hline Phenyl ethyl alcohol & 1109 & tr. & 0.45 \\
\hline \multicolumn{4}{|c|}{ Esters } \\
\hline Ethyl-hexadecanoate & 1996 & $\operatorname{tr}$ & 0.35 \\
\hline Ethyl-oleate & 2165 & tr. & 0.11 \\
\hline Ethyl-octadecenoate (18:1) & 2177 & $\operatorname{tr}$. & $\operatorname{tr}$ \\
\hline Ethyl-octadecanoate (18:0) & 2197 & tr. & tr. \\
\hline \multicolumn{4}{|c|}{ Acids } \\
\hline Hexanoic acid & 969 & tr. & 5.44 \\
\hline Dodecanoic acid & 1570 & tr. & 0.09 \\
\hline Tetradecanoic acid & 1770 & $\operatorname{tr}$. & 0.40 \\
\hline Pentadecanoic acid & 1838 & tr. & 0.12 \\
\hline Hexadecanoic acid & 1969 & 6.13 & 8.87 \\
\hline \multicolumn{4}{|c|}{ Terpenes } \\
\hline$\alpha$-Terpinene & 1018 & tr. & 0.50 \\
\hline$p$-Cymene & 1024 & 0.11 & 2.86 \\
\hline Phellandrene & 1029 & 0.37 & tr. \\
\hline$\gamma$-Terpinene & 1056 & tr. & 1.02 \\
\hline Terpinen-4-ol & 1178 & 0.18 & 12.56 \\
\hline$\gamma$ Eudesmol & 1637 & 0.11 & 0.15 \\
\hline Terpinolene & 1084 & $\operatorname{tr}$ & $\operatorname{tr}$ \\
\hline$p$-Cymen-8-ol & 1186 & $\operatorname{tr}$. & tr. \\
\hline$\alpha$-Terpineol & 1193 & $\operatorname{tr}$. & $\operatorname{tr}$. \\
\hline$\alpha$-Murolene & 1505 & tr. & tr. \\
\hline Total identified compounds & & $97.69 \%$ & $96.30 \%$ \\
\hline
\end{tabular}

from oranges and mandarins, the New Zealand lemonwood tree and the Japanese cedar to black pepper. With other terpenes, it is thought to contribute to the unique taste of the Cuban bullock's heart fruit and it appears to be an odorant in Muscadet wines [22].

These results indicate that the biogenetic pathway of fatty acids is activated during the medlar fruit ripening process. Saturated and unsaturated fatty acids are formed through $\beta$-oxidation, and then transformed into their corresponding esters, which subsequently pro- duce different C6 compounds by lipoxygenase oxidation, such as: hexanal, (Z)-2-hexenal, hexanol and (Z)3-hexenol.

\section{CONCLUSIONS}

The present work is the first report on chemical composition of the volatile compounds obtained from medlar fruits that were in different stages of maturity. A total of 32 volatile components at two ripening fruits 


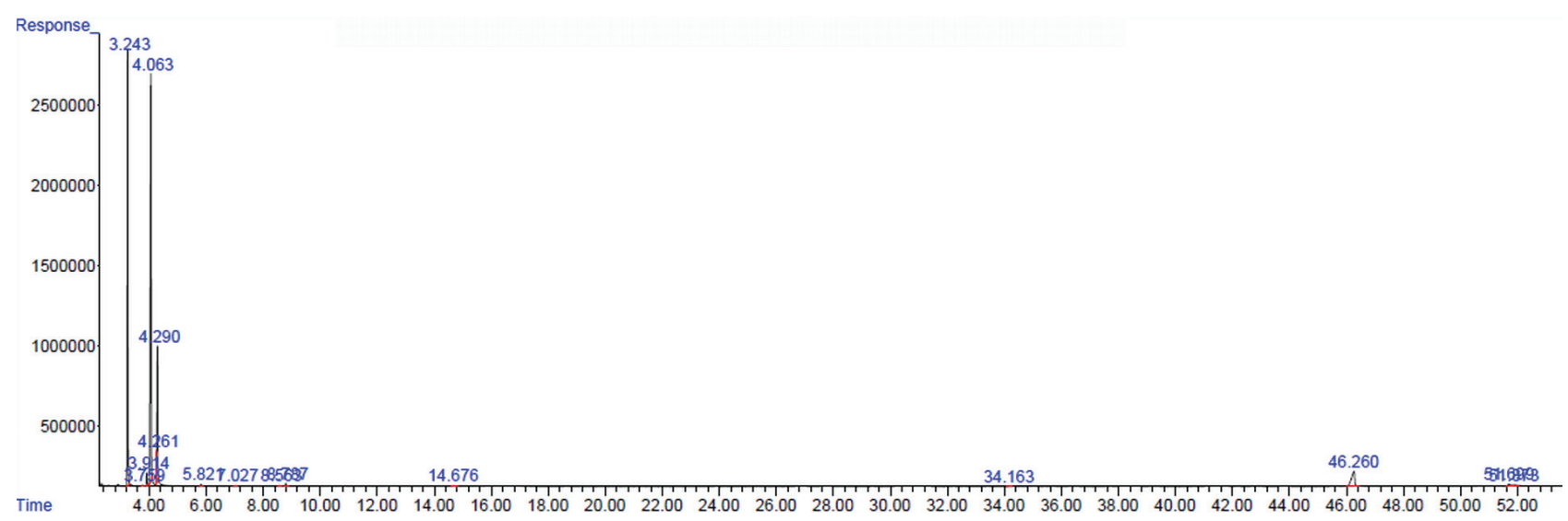

Figure 1. GC/MS Chromatogram volatile compounds unripe medlar fruits.

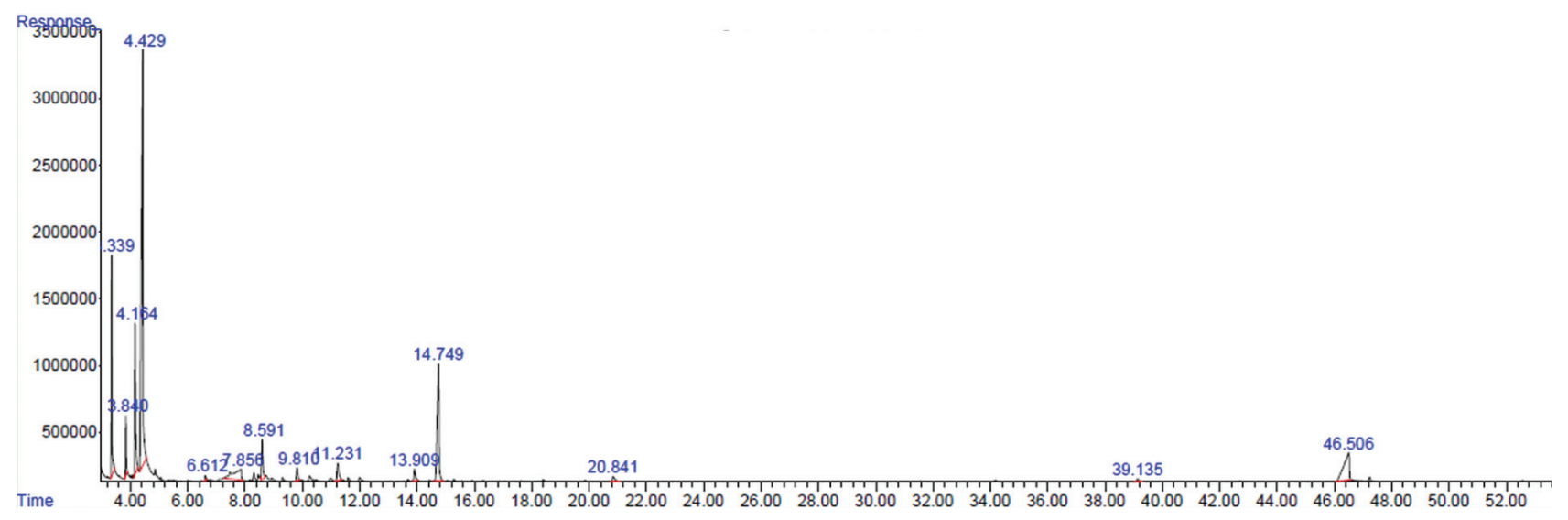

Figure 2. GC/MS Chromatogram volatile compounds ripe medlar fruits.

stages were isolated and analyzed using GC-MS. Both maturation stages had several compounds in common. Throughout medlar fruits maturation, hexanal and $(E)$ 2-hexenal decreased in concentration, while (Z)-3hexenol, hexanol, hexanoic acid and terpinen-4-ol with fruity odor notes, increased in content.

\section{Acknowledgements}

This study is financially supported by Ministry of Education, Science and Technological Development of the Republic of Serbia, Projects No. 172053, III46001, 31093 and 31063.

\section{REFERENCES}

[1] M.A. Dirr, in: Manual of woody landscape plants: their identification, ornamental characteristics, culture, propagation and uses, Stipes Publ. Co., Champaign, Illinois, 1990, p. 554.

[2] R.H. Glew, F.A. Ayaz, C. Sanz, D.J. VanderJagt, H.S. Huang, L.T. Chuang M. Strnad, Changes in sugars, organic acids and amino acids in medlar (Mespilus germanica L.) during fruit development, Food Chem. 83 (2003) 363-369.

[3] F.A. Ayaz, R.H. Glew, H.S. Huang, L.T. Chuang, D.J. VanderJagt, M. Strnad, Evolution of fatty acids in medlar
(Mespilus germanica L.) mesocarp at different stages of ripening, Grasas Aceites 53 (2002) 352-356.

[4] R.H. Glew, F.A. Ayaz, D.J. VanderJagt, M. Millson, R. Dris, R. Niskanen, A research note mineral composition of medlar (Mespilus germanica) fruit at different stages of maturity, J. Food Quality 26 (2003) 441-447.

[5] R.H. Glew, F.A. Ayaz, C. Sanz, D.J. VanderJagt, H.S. Huang, L.T. Chuang, M. Strnad, Changes in sugars, organic acids and amino acids in medlar (Mespilus germanica L.) during fruit development, Food Chem. 83 (2003) 363-369.

[6] F.A. Ayaz, H.S. Huang, L.T. Chuang, D.J. VanderJagt, R.H. Glew, The fatty acid composition of medlar (Mespilus germanica) fruit at different stages of development, Ital. J. Food Sci. 14 (2002) 439-445.

[7] J. Gruz , F.A. Ayaz, H. Torun, M. Strnad, Phenolic acid content and radical scavenging activity of extracts from medlar (Mespilus germanica L.) fruit at different stages of ripening, Food Chem. 124 (2011) 271-277.

[8] A. Hatanaka, The biogeneration of green odour by green leaves, Phytochemistry 34 (1995) 1201-1218.

[9] C. Fisher, T.R. Scott, Food Flavours, Biology and Chemistry, The Royal Society of Chemistry, Cambridge, United Kingdom, 1997. p. 26.

[10] S.M. Pourmortazavi, M. Ghadiri, S.S. Hajimirsadeghi, Supercritical fluid extraction of volatile components from Bunium persicum Boiss. (black cumin) and Mes- 
pilus germanica L. (medlar) seeds., J. Food Comp. Anal. 18 (2005) 439-446.

[11] A.R. Rodriguez, J.S. Lozano, L.V. Oderiz, J.L. Hernandez, M.J. Gonzalez, Physical, physicochemical and chemical changes during maturation of medlards and persimmons, Dtsch. Lebensm-Rundsch. 96 (2000) 142-145.

[12] O. Rop, J. Sochor, T. Jurikova, O. Zitka, H. Skutkova, J. Mlcek, P. Salas, B. Krska, P. Babula, V. Adam, D. Kramarova, M.a Beklova, I. Provaznik, R. Kizek, Effect of five different stages of ripening on chemical compounds in medlar (Mespilus germanica L.), Molecules 16 (2011) 74-91.

[13] E.A. Baldwin, Flavor, in: The Commercial Storage of Fruits, Vegetables, and Florist and Nursery Stocks, USDA, ARS Agriculture Handbook Number 66, http:// //usna.usda.gov/ hb66/023flavor.pdf, 2004, p. 18.

[14] S.A. Goff, H.J. Klee, Plant volatile compounds: sensory cues for health and nutritional value, Science 311 (2006) 815-819.

[15] A.S. Gholap, C. Bandyopadhyay, Fatty acid biogenesis in ripening mango (Mangifera indica L. var Alphonso), J. Agric. Food Chem. 28 (1980) 839-841.

[16] M.K. Supran, Lipids as a source of flavor, ACS Symposium Series 75, American Chemical Society, Washington, DC, 1978, pp. 11-12.
[17] C.F Carson, T.V Riley, Antimicrobial activity of the major components of the essential oil of Melaleuca alternifolia, J. Appl. Bacteriol. 78 (1995) 264-269.

[18] K.A. Hammer, C.F. Carson, T.V. Riley, Antifungal activity of the components of Melaleuca alternifolia (tea tree) oil, J. Appl. Microbiol. 95 (2003) 853-860.

[19] S.F. Walton, M.R. Myerscough, B.J. Currie, Studies in vitro on the relative efficacy of current acaricides for Sarcoptes scabiei var.hominis. Trans. Roy. Soc. Trop. Med. Hyg. 94 (2000) 92-96.

[20] S. Lahlou, L.F. Interaminense, Leal-Cardoso, G.P. Duarte Antihypertensive effects of the essential oil of Alpinia zerumbet and its main constituent, terpinen-4-ol, in DOCA-salt hypertensive conscious rats, Fundam. Clin. Pharm. 17 (2003) 323-330.

[21] T. Matsunaga, C. Hasegawa, T. Kawasuji, H .Suzuki, H. Saito, T. Sagioka, R. Takahashi, H. Tsukamoto, T. Morikawa, T. Akiyama. Isolation of the anti-ulcer compound in essential oil from the leaves of Cryptomeria japonica, Biol. Pharm. Bull. 23 (2000) 595-598.

[22] R.D. Camp, The wizard of $\mathrm{Oz}$, or the intriguing tale of the tea tree. J. Invest. Dermatol. 123 (2004) xviii-xix.

\section{ISPARLIVA JEDINJENJA IZ PLODA MUŠMULE (Mespilus germanica L.) U DVE FAZE ZRENJA}

Milovan M. Veličković ${ }^{1}$, Dragan D. Radivojević ${ }^{1}$, Čedo Đ. Oparnica ${ }^{1}$, Ninoslav J. Nikićević ${ }^{1}$, Marijana B. Živković ${ }^{2}$, Neda O. Đorđević ${ }^{2}$, Vele V.Tešević ${ }^{3}$

${ }^{1}$ Univerzitet u Beogradu, Poljoprivredni fakultet, Zemun, Srbija

${ }^{2}$ Univerzitet u Beogradu, Institut za hemiju, tehnologiju i metalurgiju, Beograd, Srbija

${ }^{3}$ Univerzitet u Beogradu, Hemijski fakultet, Beograd, Srbija

(Kratko saopštenje)

Mušmula (Mespilus germanica $\mathrm{L}$ ) je voće iz porodice ruža (Rosaceae). Zeleni plodovi mušmule nisu jestivi već treba da ugnile (omekšaju usled mraza ili tokom čuvanja) pre nego što se koriste $u$ ishrani. Efekat procesa sazrevanja na isparljive komponente ploda mušmule ispitivan je u dve različite faze njegove zrelosti. Isparljiva jedinjenja su izolovana iz izmrvljene pulpe nezrelih i zrelih plodova mušmule pomoću simultane destilacije vodenom parom i ekstrakcije metilen-hloridom. Koncentrovani uzorak je analiziran kombinacijom metoda GC-FID-MS. Heksanska i palmitinska kiselina su najzastupljenije kiseline, heksanal i $(E)$-2-heksenal su najzastupljeniji aldehidi, (Z)-3-heksenol i heksanol su najzastupljeniji alkoholi i $p$-cimen, terpinen-4-ol i $\gamma$ terpinen, terpeni odgovorni za karakterističnu aromu ploda mušmule, takođe su prisutni. C6 alifatična jedinjenja, kao što su heksanal i (E)-2-heksenal su nađeni kao glavne isparljive komponente zelenih mušmula. Za razliku od njih, heksanol, (Z)-3-heksenol su glavne komponente zrelih plodova mušmule.

Ključne reči: Mušmula • Miris • Sazrevanje $\bullet \mathrm{GH} / \mathrm{MS}$ 